\title{
The Effect of Twisted Polymer Fiber on Physical and Mechanical Characteristics of Concrete C35
}

\author{
Reza Mirzaei, Naser Zarifmoghaddam \\ Department of Civil Engineering, Torbat-e Heydarieh Branch, Islamic Azad University, Iran \\ Corresponding author: nasser_zarif@yahoo.com
}

Received: Nov 7, 2017 Revised: Jan 3, 2018 Accepted: Jan 13, 2018

\begin{abstract}
Concrete as the most used material, is known as an integral part of construction. So far, many studies have been done in the field of improving the quality of concrete that most of them have examined change in concrete mix which is called concrete mix plan. However, the use of additives and also replacing commonly used materials in concrete with new materials always has been noteworthy. In this study, description of tests that have been done on fiber reinforced concrete will be discussed. Also, the condition of concrete mix plan will be discussed. Comparison between results of the tests showed that Forta reinforced concretes have more compressive, flexural and tensile strength and modulus of elasticity than normal and ordinary concretes.
\end{abstract}

Key words: Concrete, forta fiber, compression test, bending test, tensile test, modulus of elasticity

\section{Introduction}

In the developed world regarding to the process that have been made in various fields of science, concrete industry has also been transformed. Production of special concretes is also the result of this progress, type of concrete that reduce the force that effects on structure because of earthquake acceleration in addition to reduction of dead load of the building and in the case of demolition debris resulting weight is also reduced and today it is known as Century Concrete. This type of concrete has different applications according to their specific characteristics that is separated according to its density and compressive strength [6].

Cement and concrete made with Portland Concrete is one of the most used materials in construction in the world. These materials have brittle behavior and some significant disadvantages like low plasticity and weak fraction in action. Also, their tensile strength and flexural strength is relatively low compared to their compressive strength. Many efforts have been done to convert cement to a building material with desired physical and mechanical properties. Since high-strength concretes are more brittle than normal concrete researchers have been looking for ways to reinforce them and improve the behavior of these concrete types. One of the ways put forward was to use fibers as a concrete reinforcement. After the appearance of 
the first crack, the fibers bear the additional loads through bridging action, and via reducing the amount of stress concentration at the tip of crack, restraining and delaying its growth rate as well as redirecting its path, improve the strength and post-cracking behavior. Fibers also increase the tensile and bending strengths due to their resistance against the tensile stress occurring within the concrete microstructure [4].

\subsection{Forta Fibers}

The enhancement properties of concrete in fresh and hardened states, its durability and its environmental impacts are interesting topics for research. One method for increasing some engineering properties of concrete is the use of fibers as an additional basic material in the concrete mixture [2]. 2013 was the thirty-fifth year that the company FORTA located in Pennsylvania, USA, was active in the field of production and sales of various types of reinforced concrete and asphalt. Since 1978 till now, FORTA has produced, developed and promoted a complete set of artificial fibers that reinforce concrete and they have been used in a wide variety of applications. Concrete fibers are used to remove thermal armatures in concrete and it is used in cases such as: steel deck roofs, industrial floors, landscaping, parking, concrete pavements, shotcrete, prefabricated concrete parts (intended research), bridge decks, etc. these fibers reduce the shrinkage of fresh and hardened concrete, increase the vulnerability, increase resistance to fatigue and increase the hardness of concrete.

Forta fiber is composed of two different structures with different materials. One part of it is thin strands that are twisted in each other which is made of copolymer and the other part has been made of reticulated thin strands that is made of pure polypropene. The reticulated part prevents the development of surface and thicker cracks in concrete and twisted strands in the first part also play its role in prevention of primary and secondary cracks and hardened concrete after the time that it is opened in the concrete structure. Addition of steel fibers appreciably increased the ductility of lightweight aggregate concrete but did not significantly affect the value of compressive strength and the value of the indirect tensile strength and that of the modulus of rupture of lightweight high-strength [5].

Usually, polymer fibers are used for reinforcement in light concrete. Polymer fibers can be used filamentous and/or as pollen. Fibers are ineffective chemically and are very stable in alkaline environment of concrete and are resistant against plastic shrinkage cracking. The use of polymer fibers not only improves the tensile strength, flexural strength, hardness and ductility but also clearly improves resistance against impact and fracture.

Nematzadeh et al. conducted a study to increase the strength of concrete using Forta fibers and metal fibers with silica powder and nano silica in 2017. In this study, about 230 concrete samples with different percentages of fibers were produced. The aim of this study is to investigate the mechanical properties of reinforced concrete, including compressive strength, tensile strength, and modulus of elasticity, water absorption and density. In the end, adding Forta fibers in order 
to strengthen of high strength concrete brings out the reduction of the performance of concrete relative to steel fibers [3].

Fazeeli et al. [3] conducted an experimental study in 2016 on the use of Forta fiber in asphalt mix (Case Study of Karaj-Chalus Road). In this paper, Forta Aramid fibers are considered as a booster of asphalt mixers. They concluded that the use of Forta Aramid fibers not only significantly increases the asphalt mix but also improves the efficiency of asphalt, including compacting [3]. Arafa et al. [1] conducted a study on the effect of Forta fiber on the physical properties of concrete in 2013. This research was performed in experimental method and samples were prepared with different percentages of this fiber. After testing in the laboratory, the tensile strength increased about 20 to 30 percent and the flexural strength about 16 to 26 percent [1]. These fibers are made in the company Forta in USA and are distributed in Iran exclusively.

\section{Numerical Model}

A test program was arranged to evaluate the effect of fiber on behavior of concrete. Compression tests, bending tests, tensile test and also test of modulus of elasticity determination on samples with different amounts of fiber were carried out. Fig. 1a shows an example of a consumer fibers. Then the description of characteristics of samples and test and also results obtained from them are discussed. In Fig. 2a, some laboratory samples are shown.

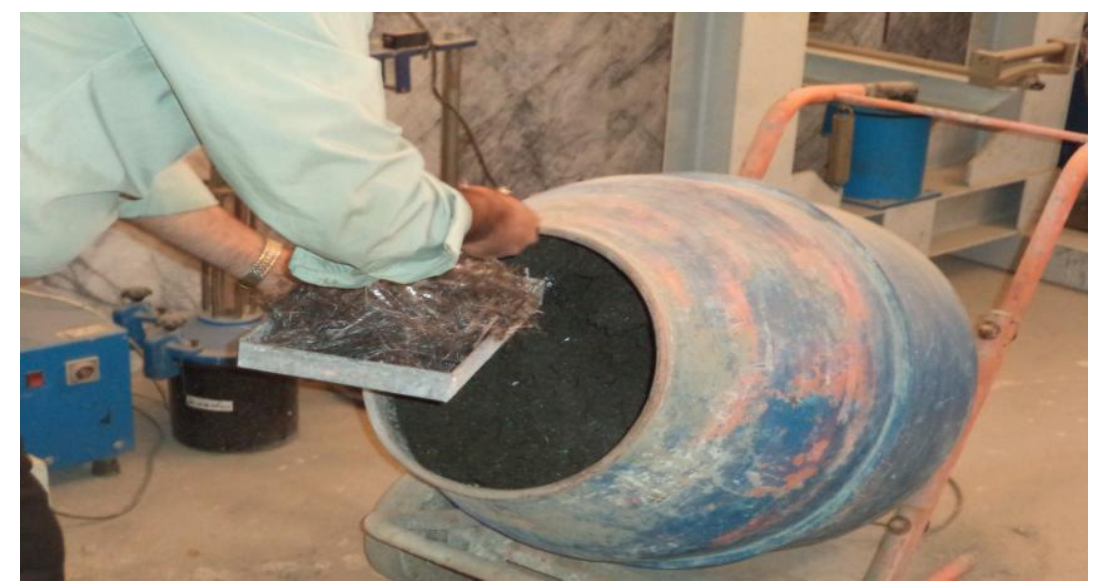

Fig. 1a: Consumer fibers

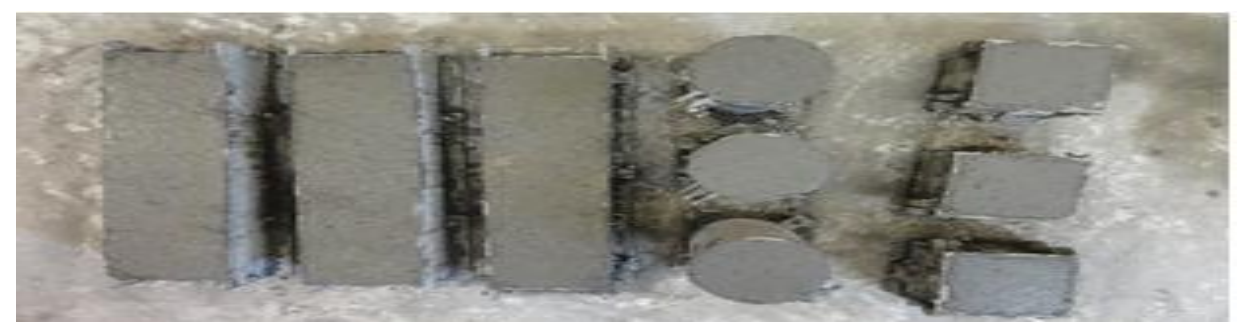

Fig. 1b: Laboratory samples 
In table 1 , the characteristics of laboratory samples have been shown. In this scheme, we have 5 groups.

Table 1: characteristics of samples

\begin{tabular}{|c|c|c|c|c|c|c|c|c|c|c|}
\hline \multirow[t]{2}{*}{ Group } & Cement & Sand & $\begin{array}{l}\text { Fine } \\
\text { sand }\end{array}$ & $\begin{array}{c}\text { Coarse } \\
\text { sand }\end{array}$ & \multirow{2}{*}{$\begin{array}{c}\text { Water- } \\
\text { cement } \\
\text { ratio } \\
\mathrm{W} / \mathrm{C}\end{array}$} & \multirow[t]{2}{*}{$\mathrm{SP} / \mathrm{C}$} & Fiber & \multirow[t]{2}{*}{$\begin{array}{l}\text { Fibers } \\
\mathrm{Wt} \%\end{array}$} & Slump & $\begin{array}{c}\text { Volume } \\
\text { of } \\
\text { samples }\end{array}$ \\
\hline & \multicolumn{4}{|c|}{$\mathrm{kg} / \mathrm{m}^{3}$} & & & $\mathrm{~kg} / \mathrm{m}^{3}$ & & $\mathrm{~m}$ & $\mathrm{~m}^{3}$ \\
\hline S1 & 350 & 1120 & 200 & 480 & 0.4 & 0.005 & 0 & 0 & 0.22 & 0.1 \\
\hline $\mathrm{S} 2$ & 350 & 1120 & 200 & 480 & 0.4 & 0.005 & 2 & 0.0086 & 0.15 & 0.1 \\
\hline S3 & 350 & 1120 & 200 & 480 & 0.4 & 0.005 & 4 & 0.0173 & 0.07 & 0.1 \\
\hline S4 & 350 & 1120 & 200 & 480 & 0.4 & 0.005 & 6 & 0.026 & 0.02 & 0.1 \\
\hline S5 & 350 & 1120 & 200 & 480 & 0.4 & 0.005 & 8 & 0.0347 & 0.01 & 0.1 \\
\hline
\end{tabular}

\subsection{Tests and Discussion}

\section{A) Pressure test}

This test is done to obtain the compressive strength if concrete using cube samples $\left(0.15^{*} 0.15^{*} 0.15 \mathrm{~m}\right)$ according to the ASTM-C $39-94^{1}$ standard test. In this test, an axial force is applied to the sample to break the concrete. The compressive strength of sample is obtained from force division on its sectional area in the time of breaking. In this study, 3 samples were tested for each concrete group with $0,2,4,6$ and $8 \mathrm{~kg}$ per cubic meter of fiber and finally, the average of their compressive strength was evaluated.
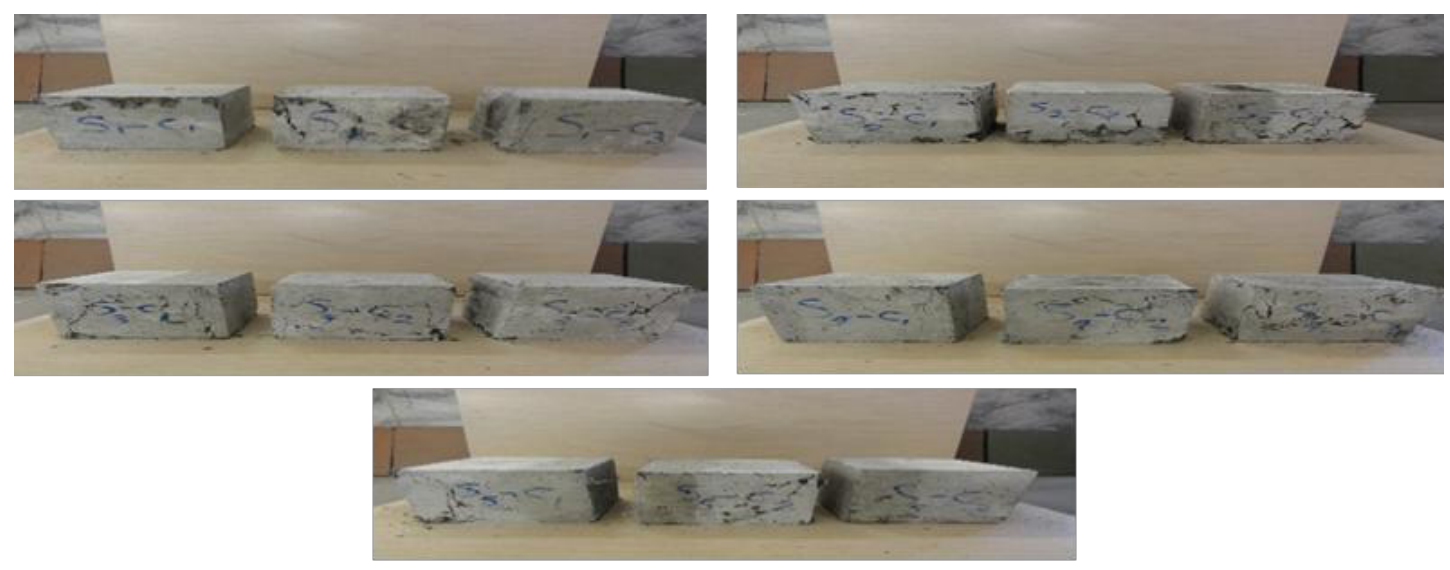

Fig. 2: Results of samples of Pressure test

\footnotetext{
${ }^{1}$ Standard Test Method for Compressive Strength of Cylindrical Concrete Specimens
} 
The result of pressure test on samples has been given in table 2 .

Table 2: Results of pressure test

\begin{tabular}{|c|c|c|c|c|c|c|c|c|}
\hline \multirow[t]{2}{*}{ Group } & \multirow[t]{2}{*}{$\begin{array}{l}\text { Group } \\
\text { name }\end{array}$} & Dimension & Weight & Density & $\begin{array}{c}\text { Final } \\
\text { load }\end{array}$ & $\begin{array}{l}\text { Compressive } \\
\text { strength }\end{array}$ & $\begin{array}{l}\text { Average } \\
\text { compressive } \\
\text { strength }\end{array}$ & $\begin{array}{c}\text { Compressive } \\
\text { strength of } \\
\text { standard } \\
\text { sample }\end{array}$ \\
\hline & & $(\mathrm{m} \times \mathrm{m} \times \mathrm{m})$ & $(\mathrm{kg})$ & $\left(\mathrm{kg} / \mathrm{m}^{3}\right)$ & (ton) & (MPa) & (MPa) & (MPa) \\
\hline \multirow{3}{*}{$\begin{array}{c}\mathrm{S} 1 \\
\left(0 \frac{\mathrm{kg}}{\mathrm{m}^{\mathrm{a}}}\right)\end{array}$} & $\mathrm{S} 1-\mathrm{C} 1$ & $15 * 15 * 15$ & 7.79 & 2308.14 & 75.5 & 33.56 & \multirow[t]{3}{*}{33.89} & \multirow[t]{3}{*}{29} \\
\hline & S1-C2 & $15 * 15 * 15$ & 7.774 & 2303.41 & 79.3 & 35.24 & & \\
\hline & S1-C3 & $15 * 15 * 15$ & 7.708 & 2283.85 & 74 & 32.89 & & \\
\hline \multirow{3}{*}{$\begin{array}{c}\mathrm{S} 2 \\
\left(2 \frac{\mathrm{kg}}{\mathrm{m}^{\mathrm{a}}}\right)\end{array}$} & S2-C1 & $15 * 15 * 15$ & 7.822 & 2317.63 & 94 & 41.78 & \multirow[t]{3}{*}{42.02} & \multirow[t]{3}{*}{36.9} \\
\hline & S2-C2 & $15 * 15 * 15$ & 8.085 & 2387.65 & 94 & 41.87 & & \\
\hline & S2-C3 & $15 * 15 * 15$ & 8.104 & 2401.87 & 96 & 42.67 & & \\
\hline \multirow{3}{*}{$\begin{array}{c}\mathrm{S} 3 \\
\left(4 \frac{\mathrm{kg}}{\mathrm{m}^{\mathrm{a}}}\right)\end{array}$} & S3-C1 & $15 * 15 * 15$ & 8.026 & 2378.07 & 97 & 43.11 & \multirow[t]{3}{*}{42.31} & \multirow[t]{3}{*}{37.11} \\
\hline & S3-C2 & $15 * 15 * 15$ & 7.83 & 2320.01 & 93.9 & 41.73 & & \\
\hline & S3-C3 & $15 * 15 * 15$ & 7.808 & 2313.48 & 94.7 & 42.09 & & \\
\hline \multirow{3}{*}{$\begin{array}{c}\mathrm{S} 4 \\
\left(6 \frac{\mathrm{kg}}{\mathrm{m}^{\mathrm{a}}}\right)\end{array}$} & S4-C1 & $15 * 15 * 15$ & 8.185 & 2417.19 & 100.4 & 44.62 & \multirow[t]{3}{*}{44.99} & \multirow[t]{3}{*}{39.81} \\
\hline & S4-C2 & $15 * 15 * 15$ & 8.03 & 2379.26 & 102.3 & 45.46 & & \\
\hline & S4-C3 & $15 * 15 * 15$ & 7.994 & 2368.59 & 101 & 44.89 & & \\
\hline \multirow{3}{*}{$\begin{array}{c}\mathrm{S} 5 \\
\left(8 \frac{\mathrm{kg}}{\mathrm{m}^{\mathrm{a}}}\right)\end{array}$} & S5-C1 & $15 * 15 * 15$ & 7.987 & 2363.5 & 102.1 & 45.38 & \multirow[t]{3}{*}{45.49} & \multirow[t]{3}{*}{40.25} \\
\hline & S5-C2 & $15 * 15 * 15$ & 8.09 & 2397.03 & 103.9 & 46.17 & & \\
\hline & S5-C3 & $15 * 15 * 15$ & 8.018 & 2375.1 & 101.1 & 44.93 & & \\
\hline
\end{tabular}

As seen in the table above, the compressive strength of fibrous concrete increases with increasing the amount of fiber. But the rate of this increase is not similar to the rate of increase of fibers and has not similar trend. This inconsistency can be found in samples S2 and S3. There is not much difference between the compressive strength of these two samples despite the change of the amount of their fiber. Hence, it can be concluded that the effect of fiber on compressive strength has not a fixed process.

\section{B) Bending test}

In this test, ASTM C293- $79^{2}$ standard method is used to determination of flexural strength of concrete using simple beam and loading on the midpoint. To this end, the amount of central

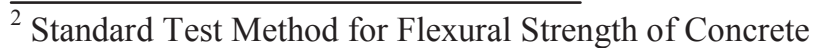


concentrated force is added gradually with the help of hydraulic jack and measure with central displacement of beam. The samples that have been tested are shown in the Fig. 3 .
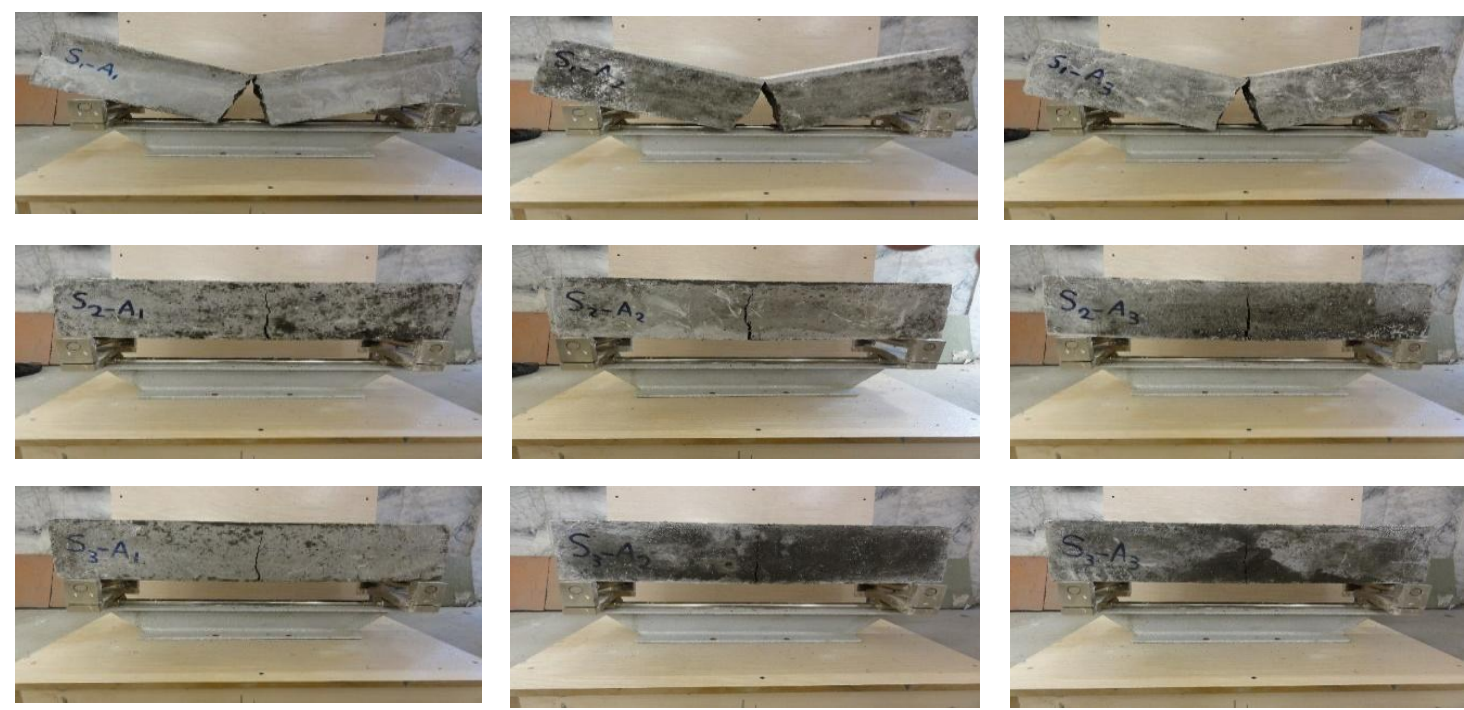

Fig. 3: Results of bending test samples

After bending test, the result has been seen in the monitor which are shown in Table 3.

Table 3: Results of flexural test

\begin{tabular}{|c|c|c|c|c|c|}
\hline \multirow[t]{2}{*}{ Group } & \multirow[t]{2}{*}{$\begin{array}{l}\text { Sample } \\
\text { name }\end{array}$} & Dimension & Final load & $\begin{array}{l}\text { Modulus of } \\
\text { rupture }\end{array}$ & $\begin{array}{c}\text { The average of modulus } \\
\text { of rupture }\end{array}$ \\
\hline & & $(\mathrm{m} \times \mathrm{m} \times \mathrm{m})$ & $(\mathrm{kg})$ & $(\mathrm{MPa})$ & $(\mathrm{MPa})$ \\
\hline \multirow{3}{*}{$\begin{array}{c}\mathrm{S} 1 \\
\left(0 \frac{\mathrm{kg}}{\mathrm{m}^{\mathrm{a}}}\right)\end{array}$} & S1-A1 & $15 * 15 * 65$ & 2900 & 7.07 & \multirow[t]{3}{*}{7.04} \\
\hline & $\mathrm{S} 1-\mathrm{A} 2$ & $15 * 15 * 65$ & 2920 & 7.13 & \\
\hline & S1-A3 & $15 * 15 * 65$ & 2840 & 6.93 & \\
\hline \multirow{3}{*}{$\begin{array}{c}\mathrm{S} 2 \\
\left(2 \frac{\mathrm{kg}}{\mathrm{m}^{\mathrm{a}}}\right)\end{array}$} & S2-A1 & $15 * 15 * 65$ & 3150 & 7.69 & \multirow[t]{3}{*}{7.62} \\
\hline & S2-A2 & $15 * 15 * 65$ & 3100 & 7.56 & \\
\hline & S2-A3 & $15 * 15 * 65$ & 3120 & 7.61 & \\
\hline \multirow{3}{*}{$\begin{array}{c}\mathrm{S} 3 \\
\left(4 \frac{\mathrm{kg}}{\mathrm{m}^{\mathrm{a}}}\right)\end{array}$} & S3-A1 & $15 * 15 * 65$ & 3150 & 7.67 & \multirow[t]{3}{*}{$7 / 67$} \\
\hline & S3-A2 & $15 * 15 * 65$ & 3120 & 7.61 & \\
\hline & S3-A3 & $15 * 15 * 65$ & 3160 & 7.72 & \\
\hline \multirow{3}{*}{$\begin{array}{c}\mathrm{S} 4 \\
\left(6 \frac{\mathrm{kg}}{\mathrm{m}^{\mathrm{a}}}\right)\end{array}$} & S4-A1 & $15 * 15 * 65$ & 3210 & 7.83 & \multirow[t]{3}{*}{7.76} \\
\hline & S4-A2 & $15 * 15 * 65$ & 3180 & 7.76 & \\
\hline & S4-A3 & $15 * 15 * 65$ & 3150 & 7.68 & \\
\hline
\end{tabular}




\begin{tabular}{|c|c|c|c|c|c|}
\hline \multirow{2}{*}{$\begin{array}{c}\mathrm{S} 5 \\
(8 g\end{array}$} & $\mathrm{kg} 5-\mathrm{A} 1$ & $15^{*} 15 * 65$ & 2860 & 6.98 & \multirow{2}{*}{7.01} \\
\cline { 2 - 5 } $\mathrm{m}^{\mathrm{a}}$ & $\mathrm{S} 5-\mathrm{A} 2$ & $15^{*} 15 * 65$ & 2770 & 6.76 \\
\cline { 2 - 5 } & $\mathrm{S} 5-\mathrm{A} 3$ & $15^{*} 15 * 65$ & 2980 & 7.27 & \\
\hline
\end{tabular}

Many researchers know the increase of amount of fiber weight and length to diameter ratio as the reason of increase in the area under the force-displacement curves. The reason of why increase of parameters of fiber weight amount and length to diameter ratio leads to improvement of flexural properties is that the number of fibers in concrete volume increase for a certain length of fiber. It is normal that if fiber has right size and direction in the fracture surface, its effect on flexural properties is more. In this test, the bending strength increases gradually by increasing the amount of fiber to 6 kilograms per cubic meter but the bending strength reduces in the case with 6 kilograms per cubic meter fiber or more (sample S5) that the reason is reduced number of fibers along the fracture surface and also reduction of density and increase of porous surface in samples with high fiber content (in this test: sample S5).

\section{C) Brazilian tensile test}

In this test, ASTM C293-79 standard method is used to determine the tensile strength with halving cylindrical samples. For the test, the cylindrical sample would be tested horizontally by the holder inside the test device. Thus, after the time that device is turned on, force would be applied to bar anchor and makes the cylinder to two halves.
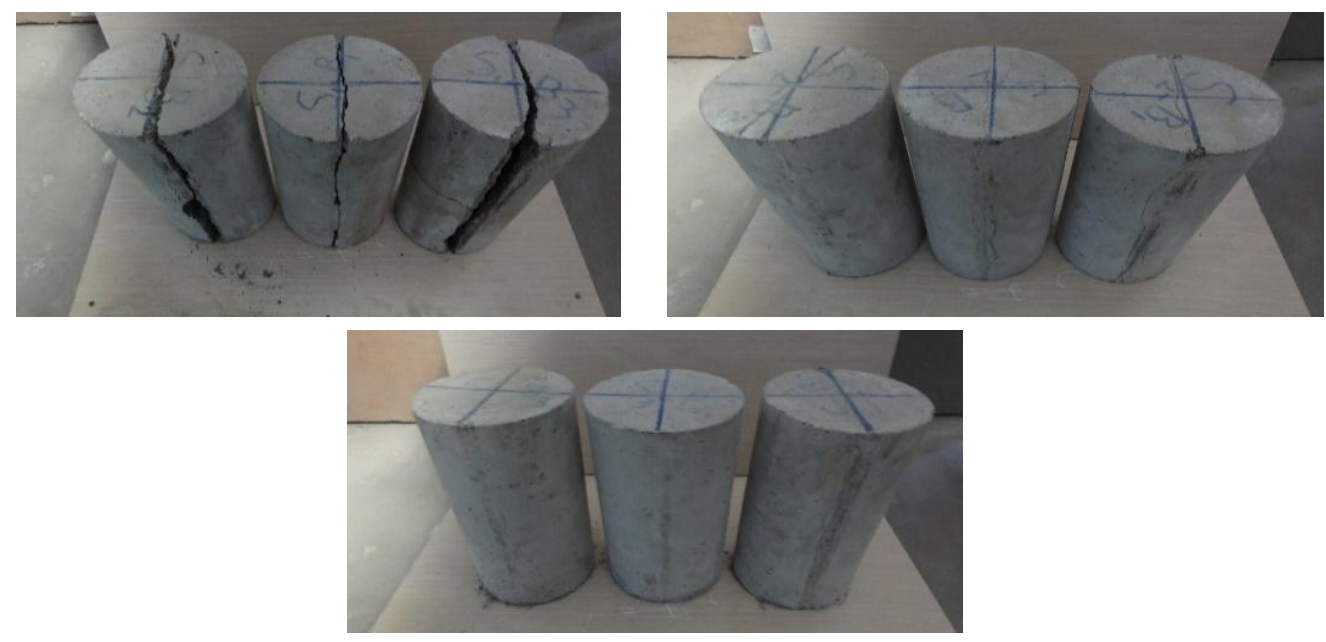

Fig. 4: Some of samples after the tensile test

The following table shows the results obtained from tensile test on five groups of test samples. 
Table 4: properties of samples and results of tensile test

\begin{tabular}{|c|c|c|c|c|c|}
\hline \multirow[t]{2}{*}{ Group } & \multirow{2}{*}{$\begin{array}{l}\text { Group } \\
\text { name }\end{array}$} & dimension & Final load & Tensile strength & \multirow{2}{*}{$\begin{array}{c}\text { Average of tensile } \\
\text { strength } \\
(\mathrm{MPa})\end{array}$} \\
\hline & & $(\mathrm{m} \times \mathrm{m})$ & (kgf) & (MPa) & \\
\hline \multirow{3}{*}{$\begin{array}{c}\mathrm{S} 1 \\
\left(0 \frac{\mathrm{kg}}{\mathrm{m}^{\mathrm{3}}}\right)\end{array}$} & S1-B1 & $0.15 * 0.3$ & 18200 & 2.57 & \multirow{3}{*}{2.58} \\
\hline & S1-B2 & $0.15^{*} 0.3$ & 18500 & 2.61 & \\
\hline & S1-B3 & $0.15 * 0.3$ & 18000 & 2.54 & \\
\hline \multirow{3}{*}{$\begin{array}{c}\mathrm{S} 2 \\
\left(2 \frac{\mathrm{kg}}{\mathrm{m}^{\mathrm{a}}}\right)\end{array}$} & S2-B1 & $0.15 * 0.3$ & 23200 & 3.28 & \multirow{3}{*}{3.28} \\
\hline & S2-B2 & $0.15^{*} 0.3$ & 23500 & 3.32 & \\
\hline & S2-B3 & $0.15 * 0.3$ & 23000 & 3.25 & \\
\hline \multirow{3}{*}{$\begin{array}{c}\mathrm{S} 3 \\
\left(4 \frac{\mathrm{kg}}{\mathrm{m}^{3}}\right)\end{array}$} & S3-B1 & $0.15 * 0.3$ & 24000 & 3.39 & \multirow{3}{*}{3.31} \\
\hline & S3-B2 & $0.15^{*} 0.3$ & 23200 & 3.28 & \\
\hline & S3-B3 & $0.15 * 0.3$ & 23000 & 3.25 & \\
\hline \multirow{3}{*}{$\begin{array}{c}\mathrm{S} 4 \\
\left(6 \frac{\mathrm{kg}}{\mathrm{m}^{3}}\right)\end{array}$} & S4-B1 & $0.15 * 0.3$ & 23200 & 3.28 & \multirow{3}{*}{3.31} \\
\hline & S4-B2 & $0.15 * 0.3$ & 23600 & 3.34 & \\
\hline & S4-B3 & $0.15 * 0.3$ & 23400 & 3.31 & \\
\hline \multirow{3}{*}{$\begin{array}{c}\mathrm{S} 5 \\
\left(8 \frac{\mathrm{kg}}{\mathrm{m}^{\mathrm{a}}}\right)\end{array}$} & S5-B1 & $0.15 * 0.3$ & 24200 & 3.42 & \multirow{3}{*}{3.43} \\
\hline & S5-B2 & $0.15 * 0.3$ & 24200 & 3.42 & \\
\hline & S5-B3 & $0.15 * 0.3$ & 24300 & 3.44 & \\
\hline
\end{tabular}

As seen in the table above, the tensile strength of concrete would increase by increasing the amount of fiber. This means that the amount of prevention of cracks would increase by adding fiber to concrete. As can be seen, this increasing trend is significant in the first sample that is reinforced with S2 fiber compared to sample S1 that has no fiber.

\section{D) Modulus of elasticity test}

To obtain the modulus of elasticity of concrete samples, concrete cylinders are used. Cylindrical samples are placed in measuring device and the axial force would be applied to them. 

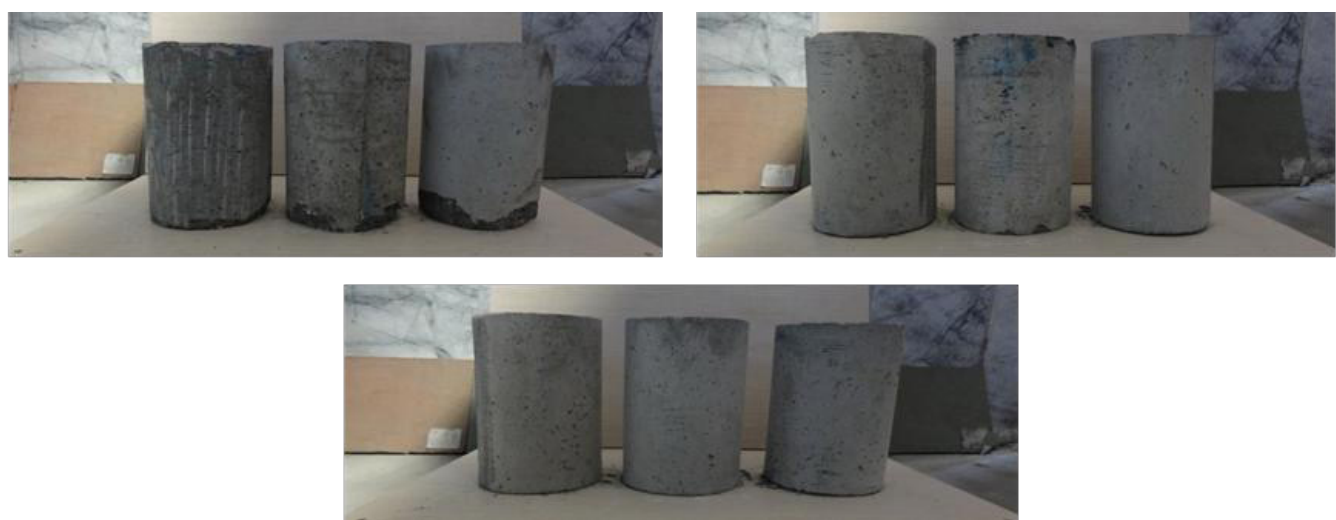

Fig. 5: Some of samples after Modulus of elasticity determination test

The following table shows the results obtained from samples under modulus of elasticity test.

Table 5: properties of samples and the result of modulus of elasticity determination test

\begin{tabular}{|c|c|c|c|c|c|c|}
\hline \multirow[t]{2}{*}{ Group } & \multirow[t]{2}{*}{$\begin{array}{l}\text { Group } \\
\text { name }\end{array}$} & Dimension & $\begin{array}{l}\text { Final } \\
\text { load } \\
* 10^{3}\end{array}$ & $\begin{array}{c}\text { Final } \\
\text { displacement } \\
* 10^{-3}\end{array}$ & $\begin{array}{l}\text { Modulus of } \\
\text { elasticity }\end{array}$ & $\begin{array}{c}\text { Average of } \\
\text { modulus of } \\
\text { elasticity }\end{array}$ \\
\hline & & $(\mathrm{m} \times \mathrm{m})$ & (kgf) & (m) & (MPa) & (Mpa) \\
\hline \multirow{3}{*}{$\begin{array}{c}\mathrm{S} 1 \\
\left(0 \frac{\mathrm{kg}}{\mathrm{m}^{\mathrm{a}}}\right)\end{array}$} & S1-D1 & $0.15 * 0.3$ & 30 & 0.173 & 29439.052 & \multirow[t]{3}{*}{28514.256} \\
\hline & S1-D2 & $0.15^{*} 0.3$ & 30 & 0.173 & 29439.052 & \\
\hline & S1-D3 & $0.15 * 0.3$ & 30 & 0.191 & 26664.691 & \\
\hline \multirow{3}{*}{$\begin{array}{c}\mathrm{S} 2 \\
\left(2 \frac{\mathrm{kg}}{\mathrm{m}^{\mathrm{a}}}\right)\end{array}$} & S2-D1 & $0.15 * 0.3$ & 40 & 0.191 & 35552.921 & \multirow[t]{3}{*}{32048.321} \\
\hline & S2-D2 & $0.15 * 0.3$ & 40 & 0.208 & 32647.152 & \\
\hline & S2-D3 & $0.15 * 0.3$ & 40 & 0.243 & 27944.889 & \\
\hline \multirow{3}{*}{$\begin{array}{c}\mathrm{S} 3 \\
\left(4 \frac{\mathrm{kg}}{\mathrm{m}^{3}}\right)\end{array}$} & S3-D1 & $0.15 * 0.3$ & 40 & 0.208 & 32647.154 & \multirow[t]{3}{*}{32672.152} \\
\hline & S3-D2 & $0.15 * 0.3$ & 40 & 0.26 & 26117.723 & \\
\hline & S3-D3 & $0.15^{*} 0.3$ & 40 & 0.173 & 39252.039 & \\
\hline \multirow{3}{*}{$\begin{array}{c}\mathrm{S} 4 \\
\left(6 \frac{\mathrm{kg}}{\mathrm{m}^{3}}\right)\end{array}$} & S4-D1 & $0.15 * 0.3$ & 40 & 0.173 & 39252.69 & \multirow[t]{3}{*}{33281.371} \\
\hline & S4-D2 & $0.15 * 0.3$ & 40 & 0.243 & 27944.889 & \\
\hline & S4-D3 & $0.15 * 0.3$ & 40 & 0.208 & 32647.154 & \\
\hline \multirow{3}{*}{$\begin{array}{c}\mathrm{S} 5 \\
\left(8 \frac{\mathrm{kg}}{\mathrm{m}^{3}}\right)\end{array}$} & S5-D1 & $0.15 * 0.3$ & 40 & 0.26 & 26117.723 & \multirow[t]{3}{*}{34873.954} \\
\hline & S5-D2 & $0.15 * 0.3$ & 40 & 0.173 & 39252.069 & \\
\hline & S5-D3 & $0.15 * 0.3$ & 40 & 0.173 & 39252.069 & \\
\hline
\end{tabular}


As seen similar to previous tests, modulus of elasticity of concrete increases by increasing the amount of fibers in it. By comparing the results of sample S1 and S2, it can be seen that existence of fiber in concrete has an important effect on increasing the modulus of elasticity.

\section{Conclusion}

The following results were obtained from the four tests conducted above:

A. Forta fibers have very good dispersion in concrete and concretes that are reinforced with these fibers have more compressive, flexural, tensile strength and modulus of elasticity than normal concrete.

B. A large increase in the weighted values of Forta fibers leads to reduction of bending strength) in this study more than 6 kilograms per cubic meter) that the reasons of this reduction are inappropriate density and drop of concrete special weight in high percentage of usage of Forta fibers.

C. Increasing the weight amount of Forta fibers has no direct effect on bending strength but directly depends on the number of appropriate fibers (fibers along the tensile force) on the fracture surface.

D. Between different values of Forta fiber in concrete, increasing amount of fiber has no significant effect on increasing the properties of fiber reinforced concrete, so using Forta fibers more than 2 kilograms per cubic meters has no economic justification.

\section{References}

[1] Arafa MH, Alqedra MA and Almassri HG (2013), Effect of Forta-Ferro Fibers on Fresh and Mechanical Properties of Ultra High Performance Self Compacting Concrete, International Journal of Engineering and Technical Research, $1: 43-47$.

[2] Bolat H, Simsek O, Culla M, Durmus G and Can B (2014), The effects of macro synthetic fiber reinforcement use on physical and mechanical properties of concrete, Some characteristics of high strength fiber reinforced lightweight aggregate concrete, Composites Part B: Engineering, 61 : 191- 198.

[3] Fazaeli H, Samin Y, Pirnoun A and Sadate Dabiri A (2016), Laboratory and field evaluation of the warm fiber reinforced high performance asphalt mixtures (case study Karaj - Chaloos Road), Construction and Building Materials, 122 : 273-283.

[4] Hasan-Nattaj F and Nematzadeh M (2017), The effect of forta-ferro and steel fibers on mechanical properties of high-strength concrete with and without silica fume and nano-silica, Construction and Building Materials, 137 : 557-572.

[5] Kayali O, Haque MN and Zhu B (2003), Cement and Concrete Composites, 25 : 207-213.

[6] Mostofinejad D (2003), Technology and Scheme of Mixing Concrete, Negarandeh Danesh, Isfahan, Iran. 